\title{
Article \\ Effect of Amino Acid and Titanium Foliar Application on Smooth-Stalked Meadow Grass (Poa pratensis L.) Macronutrient Content
}

\author{
Adam Radkowski ${ }^{1, *}++^{(D}$, Iwona Radkowska ${ }^{2}$, Jan Bocianowski ${ }^{3,+}{ }^{(D)}$, Karol Wolski ${ }^{4}$ and Henryk Bujak $^{5,6}{ }^{(D)}$ \\ 1 Department of Agroecology and Plant Production, University of Agriculture in Kraków, Mickiewicza 21, \\ 31-120 Kraków, Poland \\ 2 Department of Cattle Breeding, National Research Institute of Animal Production, Krakowska 1, \\ 32-083 Balice, Poland; iwona.radkowska@izoo.krakow.pl \\ 3 Department of Mathematical and Statistical Methods, Poznań University of Life Sciences, \\ Wojska Polskiego 28, 60-637 Poznań, Poland; jan.bocianowski@up.poznan.pl \\ 4 Department of Agroecology and Plant Production, Wrocław University of Environmental and Life Sciences, \\ Grunwaldzki 24A, 50-363 Wrocław, Poland; karol.wolski@upwr.edu.pl \\ 5 Department of Genetics, Plant Breeding and Seed Production, Wrocław University of Environmental and Life \\ Sciences, Grunwaldzki 24A, 53-363 Wrocław, Poland; henryk.bujak@upwr.edu.pl \\ 6 Research Center for Cultivar Testing (COBORU), 63-022 Słupia Wielka, Poland \\ * Correspondence: adam.radkowski@urk.edu.pl; Tel.: +48-126624359 \\ + A.R. and J.B. have contributed equally to this work.
}

\section{check for}

updates

Citation: Radkowski, A.;

Radkowska, I.; Bocianowski, J.;

Wolski, K.; Bujak, H. Effect of Amino

Acid and Titanium Foliar Application

on Smooth-Stalked Meadow Grass

(Poa pratensis L.) Macronutrient

Content. Appl. Sci. 2021, 11, 11421.

https://doi.org/

10.3390/app112311421

Academic Editor: Claudio De Pasquale

Received: 14 October 2021

Accepted: 30 November 2021

Published: 2 December 2021

Publisher's Note: MDPI stays neutra with regard to jurisdictional claims in published maps and institutional affiliations.

Copyright: (c) 2021 by the authors. Licensee MDPI, Basel, Switzerland. This article is an open access article distributed under the terms and conditions of the Creative Commons Attribution (CC BY) license (https:// creativecommons.org/licenses/by/ $4.0 /)$.

\begin{abstract}
As plant growth stimulants, Ti and amino acids affect physiological processes of plants, promoting their vegetative and generative development and improving their yield and its quality. An experiment was carried out at the Experimental Station of the University of Agriculture in Krakow on degraded black earth soil formed from loess. Its aim was to determine the effect of two products, one containing amino acids and the other with $\mathrm{Ti}$, on the Poa pratensis yield and its quality. Foliar application of amino acids and Ti, used on their own and together, constituted the main factor of the experiment. It was found that the treatment with both stimulants applied together significantly affected plant parameters. Compared to control, plants treated with those growth stimulants produced higher dry matter yields and contained significantly more phosphorus, potassium, calcium, magnesium, and sodium in dry matter. The highest effect was recorded on plots where combined application of amino acids and Ti was used. Almost as good results were recorded when amino acids were applied on their own. Regarding the cuts, higher effects were noted in the first and second ones than in the third. The growth stimulants used in the present experiment had a positive effect on the chemical composition of Poa pratensis meadow plants. The results indicated that the treatment significantly increased macronutrient content, compared to control plants. The most favourable effects were recorded for plants on the plot with combined application of amino acids and Ti. Similar results were also obtained on plots where only amino acids were used. Regarding the harvests, better results were noted in the first and second ones than in the third. In view of the potential benefits, it would be advisable to extend and update research on the effects of these stimulants on other common varieties of forage grasses.
\end{abstract}

Keywords: biostimulants; meadow plants; chemical composition; dry matter yield

\section{Introduction}

Currently, it is becoming increasingly important to use fertilizers containing ingredients adapted to plant needs, but also to use products called growth stimulants that affect physiological processes. Often used in very small quantities, such substances are necessary for the proper course of many biochemical and physiological processes taking place in plants. Nutrient uptake is mainly done by plant roots, but fertilizers can also be 
applied to leaves, and according to many studies, the latter type of treatment can be used for stimulant application $[1,2]$. Substances supplied to leaves are quickly absorbed, with nutrients readily available to plants. Additionally, foliar application of plant nutrients has economic benefits, which is why it is becoming increasingly popular [3]. Stimulants can act directly on plant physiology and metabolism or indirectly by modifying environmental conditions [4], among others, due to their beneficial effects on the soil microbiological activity. These products are usually used as an additive to standard fertilizers to improve nutrient efficiency and product quality [5].

The timing of stimulant application is very important. They should be used at plant development stages crucial for yield quality and quantity, e.g., during sowing, applied to the soil, and in the tillering or flowering stages, applied to the leaves. Stimulants are also recommended as an intervention method to help plants respond to stressful conditions such as frost, drought, hail, strong wind, and chemical contamination with pesticides. They can be used before expected stress or during adverse conditions, as well as after stress for better plant growth [6].

Many studies have reported on the ability of amino acids to reduce abiotic stress and on their beneficial effect on plant growth and yield [7]. The importance of amino acids is due to their role in the biosynthesis of many different organic compounds [8]. According to Wahba et al. [9], apart from increasing the yield and its quality, they also shorten the productive cycle. Amino acids are the building blocks of proteins, and Hounsome et al. [10] confirm that they are involved in the growth and development of plants. In addition, they are part of enzymes, nucleic acids, antioxidants, and other secondary compounds. However, for the biosynthesis of amino acids, plants require significant energy for nitrogen uptake and assimilation [11] since nitrate must be reduced to nitrite and then to ammonium, with the latter being included in the biosynthesis of amino acids [12]. Amino acids are easily absorbed and moved in plant tissues [2,13].

As growth stimulants, amino acids are mainly used in the cultivation of vegetables and fodder crops on arable land, but in recent years various biostimulants and similar products have been developed also to use on grassland [14,15]. Some of such biostimulants contain amino acids as essential ingredients [16,17].

As a microelement, Ti is also used on crops as a stimulant, which is why it was also tested in the present experiment. It has a beneficial effect on biochemical processes occurring in plants, leading to growth acceleration and an increase of their yield [18]. Ti stimulates the activity of many enzymes, e.g., catalase, peroxidase, lipoxygenase, or nitrate reductase. In addition, it accelerates metabolic processes, facilitates pollination, fertilization in flowering plants, and the setting of fruit and seeds. It increases chlorophyll content in leaves, accelerating their growth and development, and reduces the sensitivity of plants to adverse environmental conditions, increasing their resistance to fungal and bacterial diseases. In addition, it has been found that Ti has a beneficial effect on the uptake of components both from the soil and from fertilizers [19].

The aim of the study was to determine the effect of the combined foliar application of amino acids and Ti on the dry matter yield and macronutrient content in Poa pratensis harvested three times a year.

\section{Materials and Methods}

\subsection{Study Site and Soil Analysis}

The experiment was carried out at the Prusy Experimental Station $\left(50^{\circ} 07^{\prime} \mathrm{N}, 20^{\circ} 05^{\prime} \mathrm{E}\right)$ of the University of Agriculture in Krakow, Poland, on the soil classified as Haplic Chernozem. Chemical properties of the soil were as follows: $\mathrm{pH} \mathrm{KCl}-6.8, \mathrm{~N}_{\text {total }}-2.52 \mathrm{~g} \cdot \mathrm{kg}^{-1}$, $\mathrm{P}-64.23 ; \mathrm{K}-160.47$ and $\mathrm{Mg}-42.51 \mathrm{mg} \cdot \mathrm{kg}^{-1}$ in soil dry matter. In the experiment, the Struga variety of Poa pratensis was used, registered in the National Register 7 March 2011 by Małopolska Plant Breeding Station in Kraków (Poland). 


\subsection{Weather Conditions}

Total annual precipitation in 2020 was $605.1 \mathrm{~mm}$, while average total rainfall during the growing period (April to September) was $385.2 \mathrm{~mm}$ (Figure 1). The average annual temperature was $10.1^{\circ} \mathrm{C}$, and for the April-September period it was $16.0^{\circ} \mathrm{C}$.

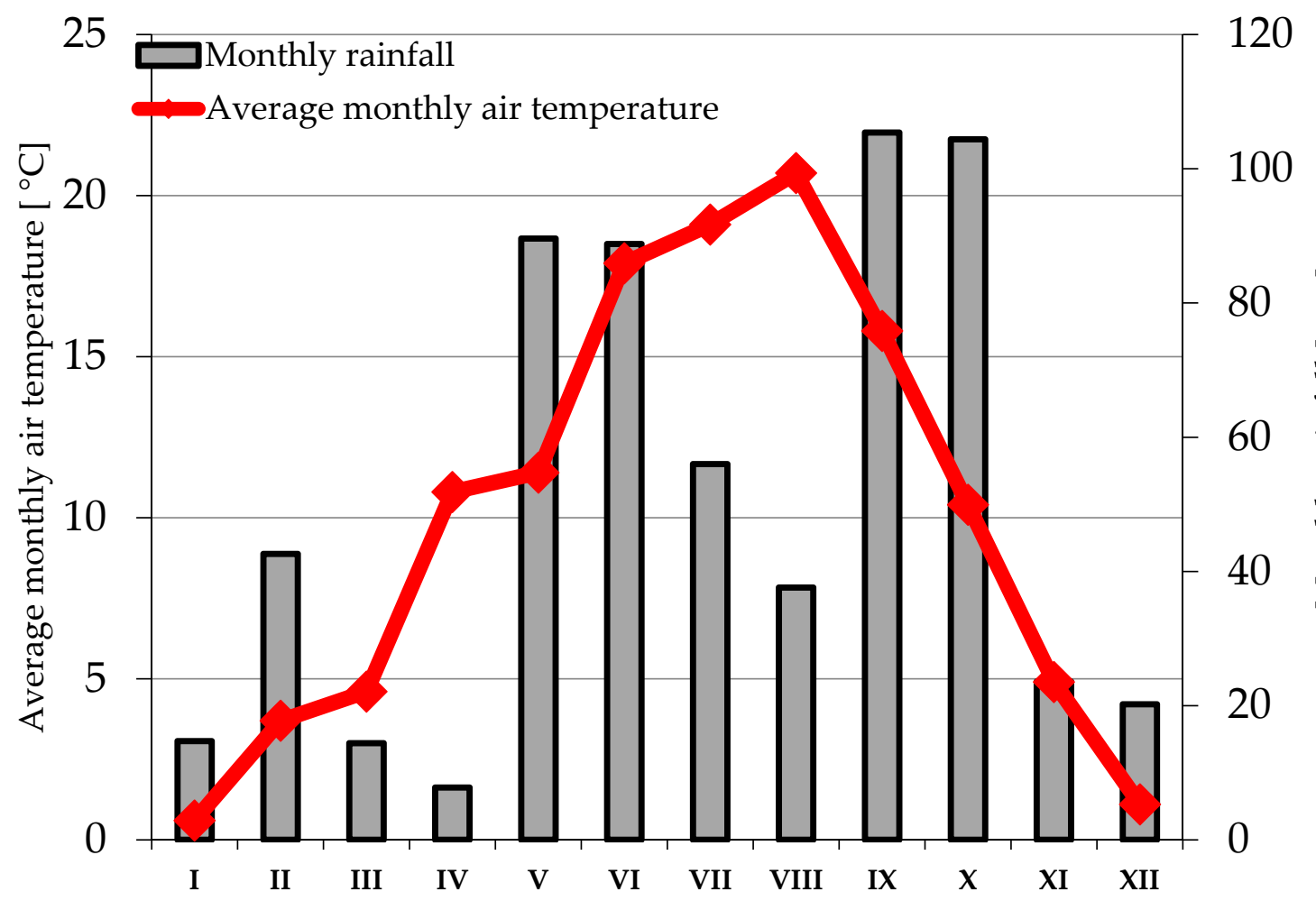

Figure 1. Rainfall and average air temperature at the Prusy Experimental Station of the Agricultural University of Krakow in the years 2020 .

\subsection{Materials and Experimental Design}

The experiment was established using randomized blocks with four replications (plots of $1.5 \times 6.67 \mathrm{~m}^{2}$ ). The following treatment units were included: (1) control plots (with no treatment) (2) plots sprayed with AGRO-SORB ${ }^{\circledR}$ Folium, containing amino acids, at a dose of $2 \mathrm{dm}^{3} \cdot \mathrm{ha}^{-1}$, (3) plots sprayed with Tytanit ${ }^{\circledR}$, containing Ti, at a dose of $0.4 \mathrm{dm}^{3} \cdot \mathrm{ha}^{-1}$, (4) plots sprayed with both AGRO-SORB ${ }^{\circledR}$ Folium at a dose of $2 \mathrm{dm}^{3} \cdot \mathrm{ha}^{-1}$ and with Tytanit ${ }^{\circledR}$ at a dose of $0.4 \mathrm{dm}^{3} \cdot \mathrm{ha}^{-1}$. Treatment was carried out three times a year, before each growth cycle. The first foliar spraying was conducted within 5 days after the start of the growing season, while the second and third 5-6 days after the first and second harvests.

The spraying liquid was prepared by dissolving the appropriate amounts of amino acid and Ti products in a volume of water needed for a dose of $300 \mathrm{dm}^{3} \cdot \mathrm{ha}^{-1}$. The amino acid product used in the experiment was AGRO-SORB ${ }^{\circledR}$ Folium produced by BIOPHARMACOTECH Ltd. (limited partnership) with its registered office in Częstochowa (Poland). It is a growth stimulant with biologically active 18 free amino acids (L-alpha) obtained by enzymatic hydrolysis. In its composition the product contains the following amino acids (at least $9.3 \%$ by weight, $100 \mathrm{~g}$ in $1000 \mathrm{~mL}$ ): aspartic acid $0.450 \%$, serine $0.321 \%$, glutamic acid $1.814 \%$, glycine $2.743 \%$, histidine $0.208 \%$, arginine $0.131 \%$, threonine $0.323 \%$, alanine $0.524 \%$, proline $0.347 \%$, cysteine $0.435 \%$, tyrosine $0.174 \%$, valine $0.551 \%$, methionine $0.349 \%$, lysine $0.661 \%$, isoleucine $0.308 \%$, leucine $0.180 \%$, phenylalanine $0.218 \%$ and tryptophan $0.05 \%$. In turn, Titanite ${ }^{\circledR}$ contains $8.5 \mathrm{~g}$ of Ti in 1 litre of solution. The product is classified as a mineral growth stimulant (Ministry of Agriculture, decision No. S-237/11), produced by INTERMAG Ltd. in Olkusz, Poland. 
During the research period, basic mineral fertilizers were also applied: $80 \mathrm{~kg} \mathrm{~N} \mathrm{ha}^{-1}$ before the first growth cycle and $60 \mathrm{~kg} \mathrm{~N} \mathrm{ha}^{-1}$ before the second and third, as $34 \% \mathrm{~N}$ ammonium nitrate. Phosphorus was used once in the spring in the amount of $34.9 \mathrm{~kg} \mathrm{P}^{-1}$ in the form of enriched superphosphate of $17.4 \% \mathrm{P}$ and potassium before the first and third growth cycle as $49.8 \%$ potassium salt of $49.8 \mathrm{~kg} \mathrm{~K} \mathrm{ha}^{-1}$. The grass was harvested at a height of 6-7 cm, at the earing stage in the first cut and after seven weeks of growth in the second and third.

In the collected plant material, the chemical composition was determined. Dry matter content was measured by drying the plant material at a temperature of $105^{\circ} \mathrm{C}$. Determination of the content of minerals, i.e., calcium, magnesium, potassium, sodium, was performed by atomic absorption spectrometry with atomization in the flame (the FAAS method, spectrometer Varian AA240FS), according to Polish Standard PN-EN 15505:2009. In turn, the determination of the total phosphorus content was performed by UV-VIS spectrophotometry, with an addition of a mixture of ammonium monovanadate (V), ammonium, and heptamolybdate as a coloring reagent, after prior mineralization of the sample according to Polish Standard PN-ISO 13730:1999.

\subsection{Statistical Analysis}

The normality of the distribution of the six traits, i.e., the yield of dry matter and the content of $\mathrm{P}, \mathrm{K}, \mathrm{Ca}, \mathrm{Mg}$, and $\mathrm{Na}$, was verified with Shapiro-Wilk's normality test to check whether the analysis of variance (ANOVA) met the assumption that the ANOVA model residuals followed normal distribution. The homogeneity of variance was tested using Bartlett's test. Box's M test was used to check multivariate normality and homogeneity of variance-covariance matrices. All the traits had normal distribution. A two-way (biostimulant treatment, cut) multivariate analysis of variance (MANOVA) was performed. Following this, two-way analyses of variance (ANOVA) were performed to verify the null hypotheses of a lack of biostimulant treatment and cut effects and biostimulant treatment and cut interaction effect on the six observed traits, independently for each one. The arithmetic means and standard deviations were calculated. Moreover, Fisher's least significant differences (LSDs) were estimated at a significance level of $\alpha=0.05$. The relationships between the yield of dry matter and the content of $\mathrm{P}, \mathrm{K}, \mathrm{Ca}, \mathrm{Mg}$, and $\mathrm{Na}$ were estimated using Pearson's linear correlation coefficients for (1) each cut, and (2) the annual dry matter yield and means of content of particular macroelements across the cuts. The results were also analyzed using multivariate methods. A canonical variance analysis (CVA) was applied to present a multi-trait assessment of the similarity of the tested biostimulant treatments in a lower number of dimensions with the least possible loss of information for each cut separately and for all three cuts jointly. Mahalanobis distance was suggested as a measure of "polytrait" biostimulant similarity [20], the significance of which was verified by means of critical value D $\alpha$ called "the least significant distance" [21]. Mahalanobis distances were calculated for the biostimulants in each cut and for all three cuts jointly. The GenStat v. 18 statistical software package (VSN International) was used for the analyses.

\section{Results}

All the observed traits had normal distribution. The results of the MANOVA indicated that effects of biostimulants (Wilk's $\lambda=0.1983 ; F=3.78 ; p<0.0001$ ) and cuts (Wilk's $\lambda=0.0042 ; F=74.32 ; p<0.0001$ ) were significantly different regarding all the six quantitative traits. According to those results, the interaction between biostimulants and cuts was not significant for macronutrient content (Wilk's $\lambda=0.487 ; F=0.69 ; p=0.905$ ), but it was significant for the dry matter yield (Table 1). ANOVA indicated that the main effects of biostimulants and cuts were significant for all examined traits (Table 1). 
Table 1. Mean squares from two-way analysis of variance for six observed traits.

\begin{tabular}{cccccccc}
\hline Source of Variation & d.f. $\begin{array}{c}\text { Dry } \\
\text { Matter } \\
\text { Yiled }\end{array}$ & $\mathbf{P}$ & $\mathbf{K}$ & $\mathbf{C a}$ & $\mathbf{M g}$ & $\mathbf{N a}$ \\
\hline Block & 3 & 0.046 & 0.022 & 1.450 & 3.175 & 0.196 & 0.0002 \\
Biostimulant & 3 & $1.863^{* * *}$ & $0.099^{* *}$ & $6.631^{* * *}$ & $2.867^{* *}$ & $0.299^{* *}$ & $0.005^{*}$ \\
Cut & 2 & $39.08^{* * *}$ & $1.944^{* * *}$ & $171.8^{* * *}$ & $24.19^{* * *}$ & $7.823^{* * *}$ & $0.155^{* * *}$ \\
Biostimulant $\times$ cut interaction & 6 & $0.586^{* *}$ & 0.004 & 0.238 & 0.057 & 0.018 & 0.0002 \\
Residual & 33 & 0.167 & 0.016 & 0.314 & 0.327 & 0.033 & 0.001 \\
\hline${ }^{*} p<0.05 ;{ }^{* *} p<0.01 ;{ }^{* * *} p<0.001 ;$ df- degrees of freedom. & & & &
\end{tabular}

Average of three cuts, the yield collected from control plots, with no biostimulants, was $12.42 \mathrm{t} \cdot \mathrm{ha}^{-1}$ (Table 2). In turn, the application of the Ti product increased it by $10 \%$. On the plot where the amino acids were used, an 18\% increase in the yield was recorded, while on the plot where both biostimulants were used, the increase was $22 \%$.

Table 2. Mean values, standard deviations (s.d.), Fisher's least significant differences (LSD) and homogeneous groups of the dry matter yield $\left(\mathrm{t} \cdot \mathrm{ha}^{-1}\right)$ of Poa pratensis.

\begin{tabular}{|c|c|c|c|c|c|c|c|c|c|c|c|}
\hline \multirow{2}{*}{ Biostimulant } & \multirow{2}{*}{ Cut } & \multicolumn{2}{|c|}{ Control } & \multicolumn{2}{|c|}{$\mathrm{Ti}$} & \multicolumn{2}{|c|}{ Amino Acids } & \multicolumn{2}{|c|}{ Amino Acids + Ti } & \multicolumn{2}{|c|}{ Average } \\
\hline & & Mean & s.d. & Mean & s.d. & Mean & s.d. & Mean & s.d. & Mean & s.d. \\
\hline \multirow{3}{*}{ Control } & $\mathrm{I}$ & $5.48 c$ & 0.455 & $6.202 b$ & 0.358 & $6.225 b$ & 0.429 & $6.889 a$ & 0.255 & 6.199 & 0.618 \\
\hline & II & $4.552 \mathrm{~d}$ & 0.391 & $4.669 \mathrm{~d}$ & 0.248 & $4.996 \mathrm{~cd}$ & 0.557 & $4.462 \mathrm{~d}$ & 0.479 & 4.67 & 0.4407 \\
\hline & III & $2.392 \mathrm{f}$ & 0.454 & $2.764 \mathrm{f}$ & 0.348 & $3.385 \mathrm{e}$ & 0.368 & $3.753 \mathrm{e}$ & 0.284 & 3.074 & 0.6379 \\
\hline \multicolumn{2}{|c|}{ Average } & 4.141 & 1.407 & 4.545 & 1.497 & 4.869 & 1.284 & 5.035 & 1.439 & & \\
\hline \multicolumn{2}{|c|}{$\operatorname{LSD}_{0.05}$} & \multicolumn{10}{|c|}{ Biostimulant: 0.328; Cut: 0.284; Biostimulant $\times$ Cut interaction: 0.568} \\
\hline
\end{tabular}

a-f-means followed by the same letters are not significantly different.

The studies showed that the use of biostimulants significantly affected the chemical composition of the Poa pratensis meadow. The weighted average of macronutrient content ranged from 1.586 to $2.424 \mathrm{~g} \mathrm{P} \mathrm{kg}^{-1} \mathrm{DM}$; from 10.90 to $18.78 \mathrm{~g} \mathrm{~K} \mathrm{~kg}^{-1} \mathrm{DM}$; from 6.098 to $9.622 \mathrm{~g} \mathrm{Ca} \mathrm{kg}^{-1} \mathrm{DM}$; from 2.024 to $3.726 \mathrm{~g} \mathrm{Mg} \mathrm{kg}^{-1} \mathrm{DM}$; from 0.289 to $0.518 \mathrm{~g} \mathrm{Na} \cdot \mathrm{kg}^{-1}$ DM. (Table 3). The biostimulants used on their own had the greatest impact on the content of phosphorus and magnesium, while combined application resulted in higher calcium content in the meadow vegetation. Plants treated with combined application of both stimulants contained, on average, $15 \%$ more calcium than control ones. According to nutritional standards, good quality forage should contain at least $3.0 \mathrm{~g} \mathrm{P} \mathrm{kg}^{-1} \mathrm{DM}$; 17-20 g K kg${ }^{-1} \mathrm{DM} ; 7.0 \mathrm{~g} \mathrm{Ca} \mathrm{kg}^{-1} \mathrm{DM} ; 2.0 \mathrm{~g} \mathrm{Mg} \mathrm{kg}^{-1} \mathrm{DM}$ and $1.5-2.5 \mathrm{~g} \mathrm{Na} \mathrm{kg}^{-1} \mathrm{DM}$ [22].

The studies also revealed significant correlation between the dry matter yield and macronutrient content. The yield was positively significantly correlated with the content of $\mathrm{P}(0.810), \mathrm{K}(0.825)$ and $\mathrm{Na}(0.821)$, and negatively with the content of $\mathrm{Ca}(-0.496)$ and $\mathrm{Mg}(-0.680)$. The annual dry matter yield was correlated with the mean content of $\mathrm{P}$ (0.563), K (0.778), Ca (0.669) and $\mathrm{Mg}(0.741)$.

Figure 2 shows the variability of the dry matter yield and content of six macroelements of the control and three biostimulant treatments in terms of the first two canonical variables. In the graph, the coordinates of the point for particular biostimulant treatments are the values for the first and second canonical variables, respectively. The first two canonical variables accounted for from $97.47 \%$ (cut II) to $99.98 \%$ (all three cuts) of the total multivariate variability between the individual biostimulants. 
Table 3. Mean values, standard deviations (s.d.), Fisher's least significant differences (LSD) and homogeneous groups of the macronutrient content $\left(\mathrm{g} \cdot \mathrm{kg}^{-1} \mathrm{DM}\right)$ of Poa pratensis.

\begin{tabular}{|c|c|c|c|c|c|c|c|c|c|c|}
\hline \multirow{2}{*}{$\begin{array}{c}\text { Trait } \\
\text { Factor }\end{array}$} & \multicolumn{2}{|c|}{$\mathbf{P}$} & \multicolumn{2}{|c|}{$\mathbf{K}$} & \multicolumn{2}{|c|}{$\mathrm{Ca}$} & \multicolumn{2}{|c|}{ Mg } & \multicolumn{2}{|c|}{$\mathbf{N a}$} \\
\hline & Mean & s.d. & Mean & s.d. & Mean & s.d. & Mean & s.d. & Mean & s.d. \\
\hline Control & $1.784 \mathrm{c}$ & 0.337 & $12.85 \mathrm{c}$ & 2.737 & $7.437 \mathrm{~b}$ & 1.215 & $2.77 \mathrm{c}$ & 0.6003 & $0.352 b$ & 0.0897 \\
\hline Titanium & $1.867 \mathrm{bc}$ & 0.2937 & $13.39 b$ & 2.73 & $7.74 b$ & 1.076 & $2.939 b$ & 0.5948 & $0.369 \mathrm{ab}$ & 0.0862 \\
\hline Amino acids & $1.955 \mathrm{ab}$ & 0.3151 & $13.86 \mathrm{~b}$ & 2.754 & 7.997ab & 1.369 & $3.05 \mathrm{ab}$ & 0.6135 & $0.387 \mathrm{a}$ & 0.0883 \\
\hline Amino acids + Titanium & $1.986 a$ & 0.3331 & $14.6 \mathrm{a}$ & 3.187 & $8.589 a$ & 1.318 & $3.136 a$ & 0.702 & $0.3961 \mathrm{a}$ & 0.0958 \\
\hline $\mathrm{LSD}_{0.05}$ & 0.107 & & 0.524 & & 0.617 & & 0.178 & & 0.029 & \\
\hline Cut & Mean & s.d. & Mean & s.d. & Mean & s.d. & Mean & s.d. & Mean & s.d. \\
\hline $\mathrm{I}$ & $2.299 \mathrm{a}$ & 0.1622 & $17.45 a$ & 1.0668 & $6.533 b$ & 0.4528 & $2.173 c$ & 0.1246 & $0.4889 a$ & 0.0498 \\
\hline II & $1.728 \mathrm{~b}$ & 0.1428 & $11.92 b$ & 0.8992 & $8.808 \mathrm{a}$ & 1.0599 & $3.466 a$ & 0.3443 & $0.3321 b$ & 0.0318 \\
\hline III & $1.667 \mathrm{~b}$ & 0.1209 & $11.65 b$ & 0.6602 & $8.481 \mathrm{a}$ & 0.7745 & $3.282 b$ & 0.2094 & $0.3071 b$ & 0.0223 \\
\hline $\mathrm{LSD}_{0.05}$ & 0.093 & & 0.454 & & 0.534 & & 0.154 & & 0.025 & \\
\hline
\end{tabular}

a-c-In columns, means followed by the same letters are not significantly different.

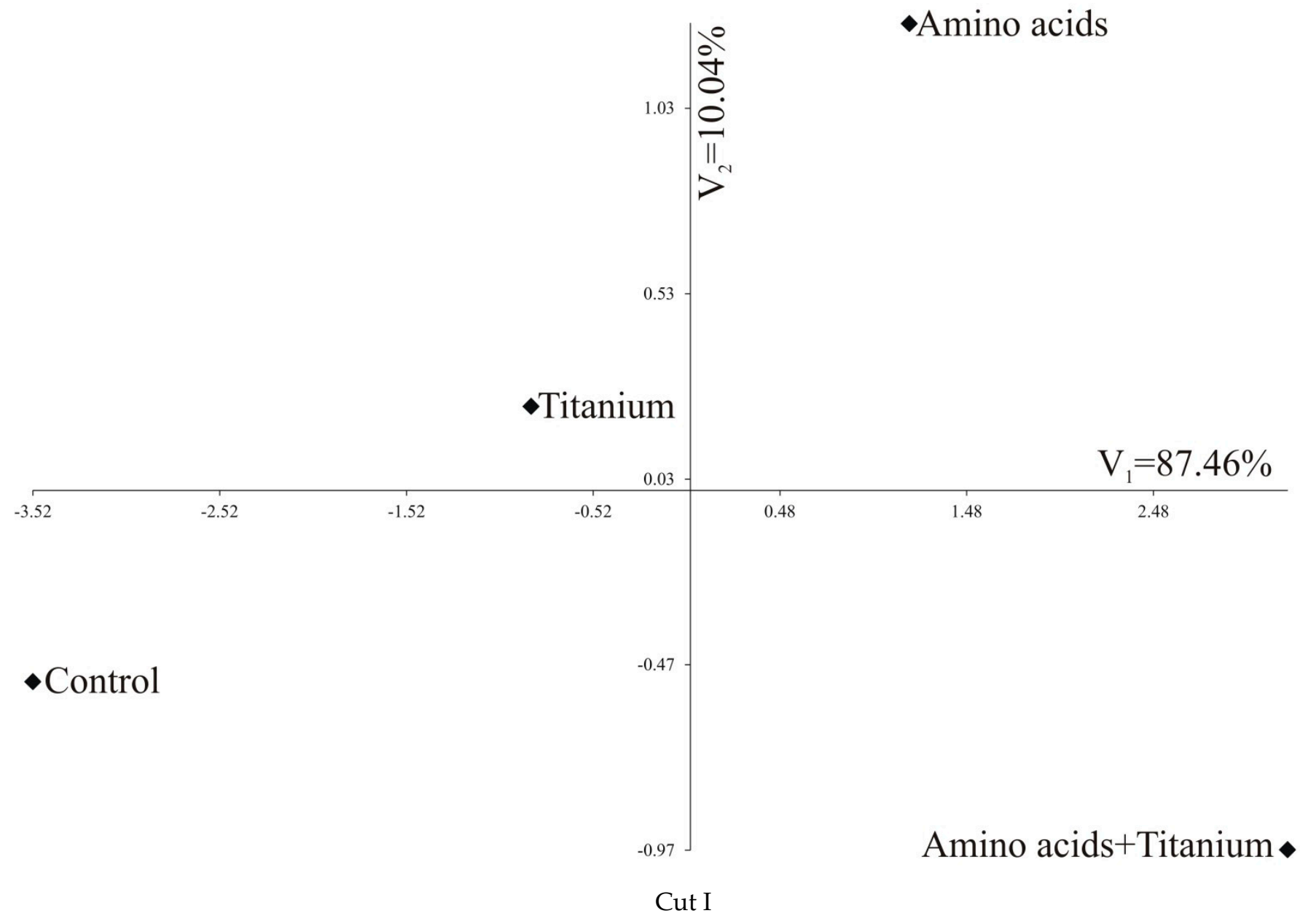

Figure 2. Cont. 

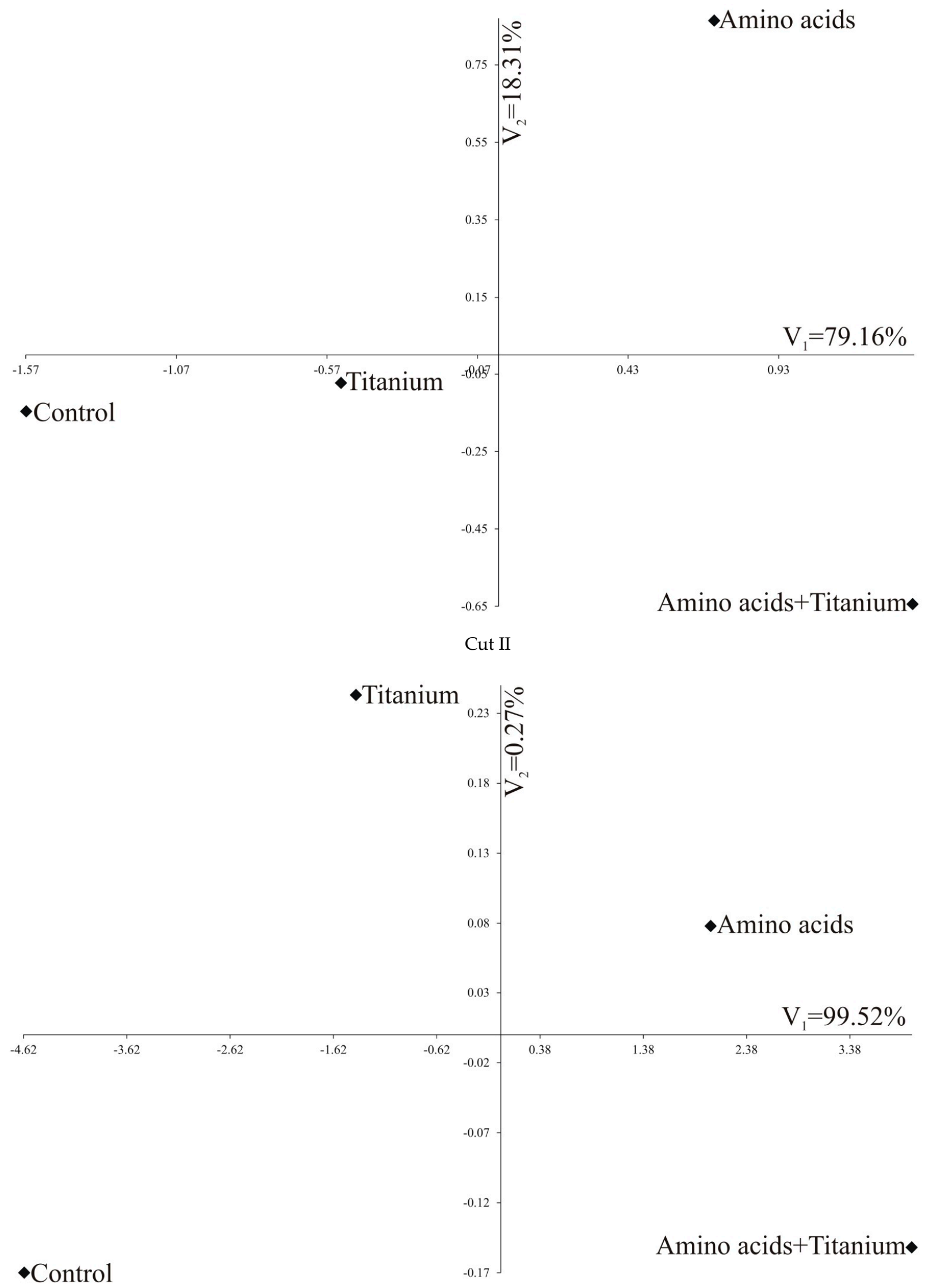

Cut III

Figure 2. Cont. 


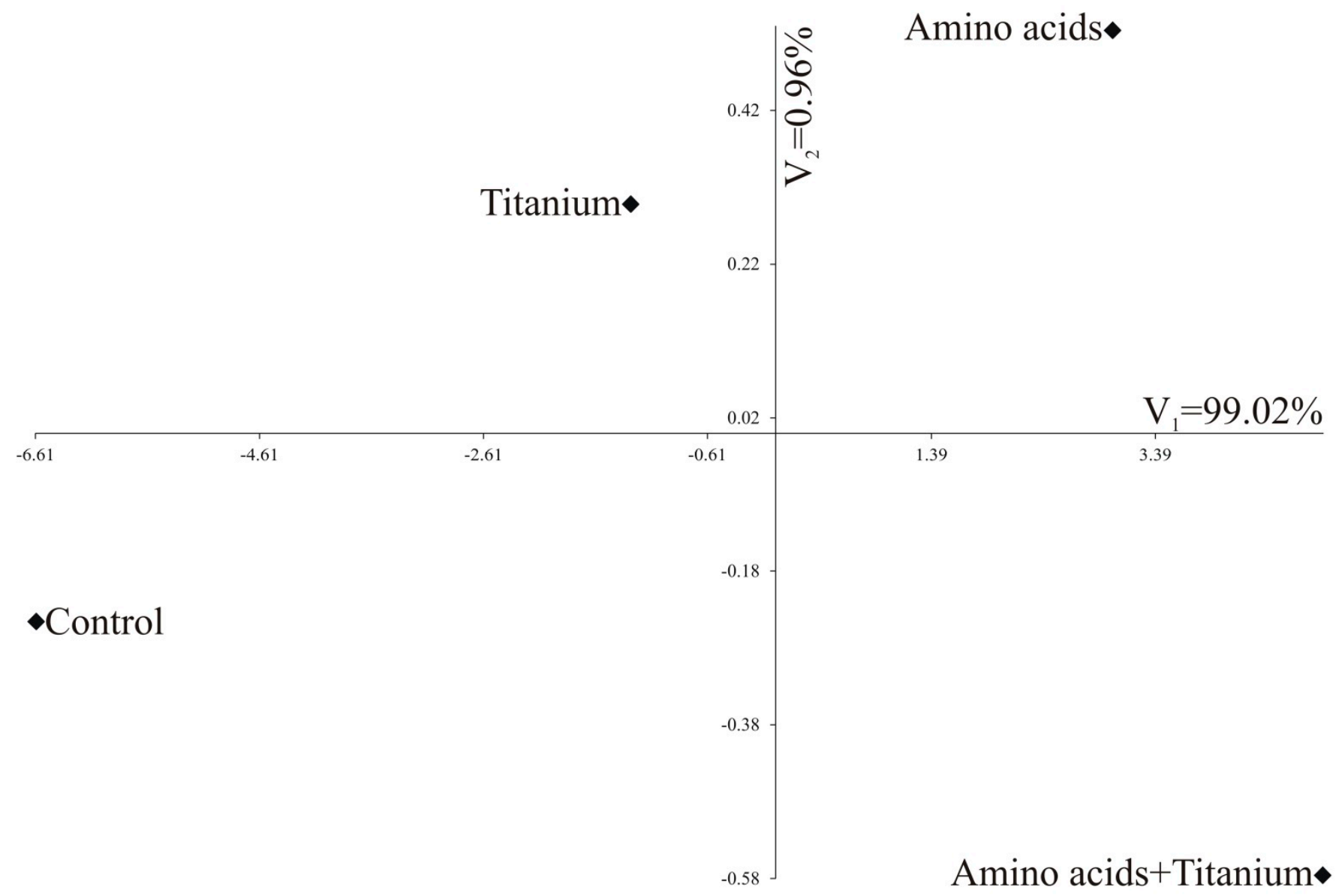

Cut I-III

Figure 2. Distribution of biostimulant treatments in space of two first canonical variables for particular cuts and for all three cuts jointly.

The greatest variation in terms of all the traits, based on the measured Mahalanobis distances, for cut I was found for control and amino acids + Ti (the Mahalanobis distance between them amounted to 6.740). The greatest similarity for cut I was found for amino acids and $\mathrm{Ti}$ (2.489) (Table 4, Figure 2). For cut II, the Mahalanobis distances ranged from 1.179 (between Ti and control) to 2.988 (between control and amino acids + Ti) (Table 4, Figure 2).

In cut III the greatest similarity (1.944) was observed between the effects of amino acids and amino acids $+\mathrm{Ti}$, but the largest distance (8.594) between control and amino acids + Ti (Table 4, Figure 2). For all three cuts jointly the Mahalanobis distance ranged from 2.175 (between amino acids and amino acids + Ti) to 11.491 (between control and amino acids $+\mathrm{Ti})$. 
Table 4. The values of the Mahalanobis distances for all pairs of biostimulant treatments in cut I, cut II, cut III, and all three cuts jointly.

\begin{tabular}{cccccc}
\hline Biostimulant & Cut & Control & Ti & Amino Acids & Amino Acids + Ti \\
\hline \multicolumn{7}{c}{ Control } & & 0 & 2.957 & 5.017 & Cut I \\
\hline Ti & & 1.179 & 0 & 2.489 & 4.74 \\
Amino acids & Cut II & 2.502 & 1.604 & 0 & 3.021 \\
Amino acids + Ti & & 2.988 & 2.024 & 1.646 & 0 \\
\hline & & & All three cuts jointly \\
\hline Control & & 0 & 3.243 & 6.654 & 8.594 \\
\hline Ti & & 5.337 & 0 & 3.457 & 5.395 \\
Amino acids & Cut III & 9.643 & 4.313 & 0 & 1.994 \\
Amino acids + Ti & & 11.491 & 6.241 & 2.175 & 0 \\
\hline
\end{tabular}

\section{Discussion}

Products containing amino acids are used as stimulants mainly on fruit crops, but research results [23-25] indicate that this method is also effective on forage grasses [26,27]. Application of amino acids to agricultural and horticultural crops increases the yield. Studies on soybean (Glycine max) conducted by Saeed et al. [28] showed that they positively improved the parameters of shoot growth and fresh weight, as well as the seed yield. Ahmed et al. [29] found that they significantly increased plant height, stem diameter, and the yield of fresh and dry matter of roselle (Hibiscus sabdariffa) leaves. Moreover, their beneficial effect on potato (Solanum tuberosum) was also reported, increasing plant height, vegetative growth and dry matter yields [23]. According to Koukounaras et al. [30], foliar use of amino acid mixtures increased the productivity of tomato (Solanum lycopersicum), and, according to Sadak et al. [24], the same treatment increased the content of dry matter, chlorophylls, carbohydrates and polysaccharides in broad bean (Vicia faba). Amino acids can affect the content of other compounds in plants. Amin et al. [31] found that the use of glutamine on onion (Allium cepa) increased the total content of amino acids, but also of soluble sugars and phenolic compounds. In contrast, Santi et al. [32] reported that amino acids increased the transcription of genes involved in the transport of nitrates, ammonium, phosphates, magnesium, and iron. According to Wang et al. [33], leaves sprayed with amino acid liquid fertilizer and liquid biological fertilizer (amino acid liquid fertilizer mixed with Bacillus amyloliquefaciens SQR9) increased cowpea (Vigna unguiculata) yields, compared to control.

In the present studies, the amino acid product increased, compared to control, the content of phosphorus, potassium, calcium, magnesium, and sodium in Poa pratensis absolutely dry matter. Studies by Abo Sedera et al. [34] showed that under the influence of amino acid preparations the content of nitrogen, phosphorus and potassium in strawberry (Fragaria ananassa) leaves increased significantly, compared to control. In contrast, studies by Shehata et al. [35] and El-Din et al. [36] comparing the effects of different levels of amino acids showed no significant differences in K content. Sadak et al. [24] studied the effects of amino acids on salinity tolerance and found that they significantly improved the $\mathrm{K}+\mathrm{Na}+$ ratio in leaf tissues. At the same time, the content of $\mathrm{N}, \mathrm{P}, \mathrm{K}, \mathrm{Mg}$, and $\mathrm{Ca}$ in leaves increased and sodium concentration significantly decreased. In effect, when $\mathrm{K}+$ content increased and $\mathrm{Na}+$ content decreased, salinity tolerance increased.

In turn, the exact mechanisms triggered by the other biostimulant, i.e., $\mathrm{Ti}$, are difficult to determine, also because this chemical element can improve the health of plants, but they can grow and develop well without it $[37,38]$. Several hypothetical theories about the mechanism of Ti action in plants have been proposed in the literature. Some theories suggest that the biological effects of Ti are based on inducing the plant's defence mechanism against $\mathrm{Ti}$; a low dose of this element strengthens defence mechanisms, while high (toxic) 
amounts inhibit them $[19,37,39]$. Based on their own experimental data and on studies by other authors, Carvajal and Alcaraz [19] hypothesize that the effects of Ti are based on Fe activity. Clarkson and Hanson [40] showed an increase in $\mathrm{Fe}^{2+}$ content in leaves, fruit, chloroplasts and chromoplasts after foliar application of Ti (IV) ascorbate. Taking this into account, Carvajal and Alcaraz [19] hold that in plants $\mathrm{Fe}^{2+}$ is a metabolically active form of Fe and a mobile fraction [41].

The latest theory proposed by Lyu et al. [38] assumes that the beneficial role of $\mathrm{Ti}$ in plants lies mainly in interactions with other nutrients, especially Fe. This hypothesis was extended by those authors with the conclusion that Ti and Fe can form both synergistic and antagonistic compounds. When plants lack Fe, Ti can induce the expression of genes associated with the metabolism of Fe, i.e., increasing its uptake and retention, which consequently leads to improved plant growth as plants may have proteins capable of specific or nonspecific binding to Ti. When the Ti content of plant tissues is high, Ti can compete with Fe for ligands or proteins. The phenomenon of competition can be dangerous for plants due to the high level of Ti toxicity [38,42].

According to Rouphael et al. [43], the higher productivity of plants treated with biostimulants is primarily attributed to greater nutrient absorption, osmotic regulation, and increased content of many secondary metabolites. The above findings can be summarized by the conclusions of studies conducted by Zhang and Schimidt [44], who found that positive physiological effects can be achieved using small doses of biostimulants, resulting in higher yields with better quality, and-ultimately-higher incomes for farmers.

The present research shows that natural biostimulants are an effective tool to be used in the management of grassland to stimulate plant growth and productivity. Their use in conditions of unpredictable climatic changes constitutes a sustainable and environmentally friendly agronomic practice. However, what is needed is continuous development and expansion of knowledge about their effects and the reaction of specific crops to such biostimulants. The results of the research indicate not only a significant increase in the dry matter yield, but also a modification of the chemical composition of Poa pratensis meadow plants, compared to control. The results indicate that the use of each biostimulant increased the Poa pratensis dry matter yield, but better results were recorded after using both together. Additionally, the products significantly affected the concentration of macronutrients in plants. Statistical methods as Mahalanobis distances and correlation analysis are often applied in agriculture [45-47].

It should be emphasized that despite the diversity of studies reported in the literature, their results and hypotheses indicate an incomplete understanding of the mechanism of biostimulant action, especially Ti. All the theories presented above have both strengths and weaknesses. For this reason, more research is needed to determine the mechanism of Ti action.

\section{Conclusions}

The growth stimulants used in the present experiment had a positive effect on the chemical composition of Poa pratensis meadow plants. The results indicated that the treatment significantly increased macronutrient content, compared to control plants. The most favourable effects were recorded for plants on the plot with combined application of amino acids and Ti. Similar results were also obtained on plots where only amino acids were used. Regarding the harvests, better results were noted in the first and second ones than in the third. In view of the potential benefits, it would be advisable to extend and update research on the effects of these stimulants on other common varieties of forage grasses.

Author Contributions: Conceptualization, A.R. and I.R.; methodology, A.R., J.B. and K.W.; software, J.B.; validation, J.B.; formal analysis, J.B.; investigation, A.R. and I.R.; resources, A.R. and J.B.; data curation, A.R. and J.B.; writing-original draft preparation, A.R., I.R. and J.B.; writing-review and editing, A.R., J.B. and H.B.; visualization, J.B.; supervision, A.R. and J.B. All authors have read and agreed to the published version of the manuscript. 
Funding: This research received no external funding.

Data Availability Statement: Not applicable.

Acknowledgments: The authors thank the AGRO-SORB Polish amino acids from Częstochowa for their assistance in conducting this experiment. In particular, Tomasz Harciarek, Director of Sales Companies AGRO-SORB.

Conflicts of Interest: The authors declare no conflict of interest.

\section{References}

1. Kocira, S.; Kocira, A.; Szmigielski, M.; Piecek, A.; Sagan, A.; Malaga-Tobola, U. Effect of an amino acids-containing biostimulator on common bean crop. Przem. Chem. 2015, 94, 1732-1736. [CrossRef]

2. Kocira, S. Effect of amino acid biostimulant on the yield and nutraceutical potential of soybean. Chil. J. Agric. Res. 2019, 79, 17-25. [CrossRef]

3. Kocira, A.; Lamorska, J.; Kornas, R.; Nowosad, N.; Tomaszewska, M.; Leszczyńska, D.; Kozłowicz, K.; Tabor, S. Changes in biochemistry and yield in response to biostimulants applied in bean (Phaseolus vulgaris L.). Agronomy 2020, 10, 189. [CrossRef]

4. Nardi, S.; Carletti, P.; Pizzeghello, D.; Muscolo, A. Biological activities of humic substances. In Biophysico-Chemical Processes Involving Natural Nonliving Organic Matter in Environmental Systems; Senesi, N., Xing, B., Huang, P.M., Eds.; Wiley: Hoboken, NJ, USA, 2009; Volume 2, pp. 305-340.

5. Heckman, J.R. Effect of an organic bio-stimulant on cabbage yield. J. Home Consum. Hortic. 1994, 1, 11-113. [CrossRef]

6. Glińska, S.; Bartczak, M.; Oleksiak, S.; Wolska, A.; Gabara, B.; Posmyk, M.M. Effects of anthocyanin-rich extract from red cabbage leaves on meristematic cells of Allium cepa L. roots treated with heavy metals. Ecotoxicol. Environ. Saf. 2007, 68, 343-350. [CrossRef] [PubMed]

7. Van Oosten, M.J.; Pepe, O.; De Pascale, S.; Silletti, S.; Maggio, A. The role of biostimulants and bioeffectors as alleviators of abiotic stress in crop plants. Technol. Agric. 2017, 4, 5. [CrossRef]

8. El-Said, M.A.A.; Mahdy, A.Y. Response of two wheat cultivars to foliar application with amino acids under low levels of nitrogen fertilization. Middle East J. Agric. Res. 2016, 5, 462-472.

9. Wahba, H.E.; Motawe, H.M.; Ibrahim, A.Y. Growth and chemical composition of Urtica pilulifera L. plant as influenced by foliar application of some amino acids. J. Mater. Environ. Sci. 2015, 6, 499-506.

10. Hounsome, N.; Hounsome, B.; Tomos, D.; Edwards-Jones, G. Plant metabolites and nutritional quality of vegetables. J. Food Sci. 2008, 73, R48-R65. [CrossRef]

11. Taiz, L.; Zeiger, E. Plant Physiology, 5th ed.; Sinauer Associates Inc.: Sunderland, MA, USA, 2010; p. 782.

12. Hull, R.; Liu, H. Turfgrass nitrogen: Physiology and environmental impacts. Int. Turfgrass Soc. Res. J. 2005, $10,962-975$.

13. Kocira, S. Effect of applying a biostimulant containing seaweed and amino acids on the content of fiber fractions in three soybean cultivars. Legume Res. 2019, 42, 341-347. [CrossRef]

14. Ervin, E.H.; Zhang, X. Applied physiology of natural and synthetic plant growth regulators. In Handbook of Turfgrass Management and Physiology; Pessarakli, M., Ed.; CRC Press: New York, NY, USA, 2008; pp. 171-202.

15. Schmidt, R.E.; Ervin, E.H.; Zhang, X. Questions and answers about biostimulants. Golf Course Manag. 2003, 17, 91-94. Available online: https:/ / hitechag.com.au/wp-content/uploads/sites/160/2015/10/QAbiostimulants.pdf (accessed on 7 October 2021).

16. Ervin, E.H.; LaBranche, A.; Zhang, X. Kentucky bluegrass and creeping bentgrass responses to foliar application of glycinebetaine at three ET replacement levels. Int. Turfgrass Soc. Res. J. 2009, 11, 755-764.

17. Ervin, E.H.; Zhang, X.; Askew, S.D.; Goatley, J.M., Jr. Trinexapac-ethyl, propiconazole, iron, and biostimulant effects on shaded creeping bentgrass. Horttechnology 2004, 14, 500-506. [CrossRef]

18. Pais, I. The biological importance of titanium. J. Plant Nutr. 1983, 6, 3-131. [CrossRef]

19. Carvajal, M.; Alcaraz, C.F. Why Ti is a beneficial element for plants. J. Plant Nutr. 1998, 21, 655-664. [CrossRef]

20. Seidler-Łożykowska, K.; Bocianowski, J. Evaluation of variability of morphological traits of selected caraway (Carum carvi L.) genotypes. Ind. Crop. Prod. 2012, 35, 140-145. [CrossRef]

21. Mahalanobis, P.C. On the generalized distance in statistics. Proc. Natl. Inst. Sci. India 1936, 12, 49-55.

22. Falkowski, M.; Kukułka, I.; Kozłowski, S. Właściwości Chemiczne Roślin Łąkowych; Wyd. AR Poznań: Poznań, Poland, $2000 ;$ p. 132.

23. El-Zohiri, S.S.M.; ASfour, Y.M. Effect of some organic compounds on growth and productivity of some potato cultivars. Ann. Agric. Sci. Moshtohor 2009, 47, 403-415.

24. Sadak, M.S.H.; Abdelhamid, M.T.; Schmidhalter, U. Effect of foliar application of aminoacids on plant yield and physiological parameters in bean plants irrigated with seawater. Acta Biol. Colomb. 2015, 20, 141-152. [CrossRef]

25. Kandil, A.A.; Sharief, A.E.M.; Seadh, S.E.; Altai, D.S.K. Role of humic acid and amino acids in limiting loss of nitrogen fertilizer and increasing productivity of some wheat cultivars grown under newly reclaimed sandy soil. Int. J. Adv. Res. Biol. Sci. 2016, 3, 123-136.

26. Radkowski, A.; Radkowska, I. Influence of foliar fertilization with amino acid preparations on morphological traits and seed yield of timothy. Plant Soil Environ. 2018, 64, 209-213. [CrossRef] 
27. Radkowski, A.; Radkowska, I.; Godyń, D. Effects of fertilization with amino acid preparation on dry matter yield and chemical composition of meadow plants. J. Elementol. 2018, 23, 947-958. [CrossRef]

28. Saeed, A.; Akhter, M.; Iqbal, M. Removal and Recovery of Heavy Metals from Aqueous Solution Using Papaya Wood as a New Biosorbent. Sep. Purif. Technol. 2005, 45, 25-31. [CrossRef]

29. Ahmed, Y.M.; Shalaby, E.A.; Shanan, N.T. The use of organic and inorganic cultures in improving vegetative growth, yield characters and antioxidant activity of roselle plants (Hibiscus sabdariffa L.). Afr. J. Biotechnol. 2011, 10, 1988-1996. [CrossRef]

30. Koukounaras, A.; Tsouvaltzis, P.; Siomos, A.S. Effect of root and foliar application of amino acids on the growth and yield of greenhouse tomato in different fertilization levels. J. Food Agric. Environ. 2013, 11, 644-648.

31. Amin, A.A.; Fatma, A.E.; Gharib, M.; El-Awad, A.; El-Sherbeny, M.; Rashad, A. Physiological response of onion plants to foliar application of putrescine and glutamine. Sci. Hortic. 2011, 129, 353-360. [CrossRef]

32. Santi, C.; Zamboni, A.; Varanini, Z.; Pandolfini, T. Growth stimulatory effects and genome-wide transcriptional changes produced by protein hydrolysates in maize seedlings. Front. Plant Sci. 2017, 8, 433. [CrossRef]

33. Wang, D.; Deng, X.; Wang, B.; Zhang, N.; Zhu, C.; Jiao, Z.; Li, R.; Shen, Q. Effects of foliar application of amino acid liquid fertilizers, with or without Bacillus amyloliquefaciens SQR9, on cowpea yield and leaf microbiota. PLoS ONE 2019, 14, e0222048. [CrossRef]

34. Abo Sedera, F.; Amany, A.; Abd El-Latif, A.; Bader, L.A.A.; Rezk, S.M. Effect of NPK mineral fertilizer levels and foliar application with humic and amino acids on yield and quality of strawberry. Egypt J. Appl. Sci. 2010, 25, 154-169.

35. Shehata, S.M.; Abdel-Azem Heba, S.; Abou El-Yazied, A.; El-Gizawy, A.M. Effect of Foliar Spraying with Amino Acids and Seaweed Extract on Growth Chemical Constitutes, Yield and its Quality of Celeriac Plant. Eur. J. Sci. Res. 2011, 58, $257-265$.

36. El-Din, D.M.; Mokhtar, H.M.O.; Ismael, O. Online Paper Review Analysis. Int. J. Adv. Comput. Sci. Appl. 2015, 6, $220-229$.

37. Bartnik, M.; Wierzchowska-Renke, K.; Głowniak, P.; Głowniak, K. Phenolic acids in Crithmum maritimum L. (Apiaceae) after Tytanit fertilization. Acta Soc. Bot. Pol. 2017, 86, 3560. [CrossRef]

38. Lyu, S.; Wei, X.; Chen, J.; Wang, C.; Wang, X.; Pan, D. Ti as a Beneficial Element for Crop Production. Front. Plant Sci. 2017, 8, 597. [CrossRef] [PubMed]

39. Hrubý, M.; Cígler, P.; Kuzel, S. Ti in plant nutrition. The contribution to understanding the mechanism of Ti action in plants. J. Plant Nutr. 2002, 25, 577-598. [CrossRef]

40. Clarkson, D.T.; Hanson, J.B. The mineral nutrition of higher plants. Annu. Rev. Plant Physiol. 1980, 31, 239-298. [CrossRef]

41. Uren, N.C. Forms, reactions and availability of iron in soils. J. Plant Nutr. 1984, 7, 165-176. [CrossRef]

42. Ghooshchi, F. Influence of $\mathrm{Ti}$ and bio-fertilizers on some agronomic and physiological attributes of triticale exposed to cadmium stress. Glob. NEST J. 2017, 19, 458-463. [CrossRef]

43. Rouphael, Y.; Cardarelli, M.; Bonini, P.; Colla, G. Synergistic action of a microbial-based biostimulant and a plant derived-protein hydrolysate enhances lettuce tolerance to alkalinity and salinity. Front. Plant Sci. 2017, 8, 131. [CrossRef] [PubMed]

44. Zhang, X.; Schmidt, R.E. Hormone-containing products' impact on antioxidant status of tall fescue and creeping bentgrass subjected to drought. Crop Sci. 2000, 40, 1344-1349. [CrossRef]

45. Warzecha, T.; Skrzypek, E.; Bocianowski, J.; Sutkowska, A. Impact of Selected PSII Parameters on Barley DH Lines Biomass and Yield Elements. Agronomy 2021, 11, 1705. [CrossRef]

46. Stachowiak-Wencek, A.; Bocianowski, J.; Waliszewska, H.; Borysiak, S.; Waliszewska, B.; Zborowska, M. Statistical Prediction of Biogas and Methane Yields during Anaerobic digestion Based on the Composition of Lignocellulosic Biomass. BioResources 2021, 16, 7086-7100. [CrossRef]

47. Szwarc, J.; Niemann, J.; Bocianowski, J.; Jakubus, M.; Mrówczyński, M. Connection between Nutrient Content and Resistance to Selected Pests Analyzed in Brassicaceae Hybrids. Agriculture 2021, 11, 94. [CrossRef] 